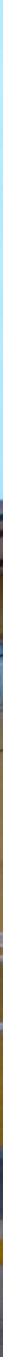

Fig. 1. Vista panorámica actual de la manzana donde se ubicó el complejo betlemita en la ciudad de Piura. Las construcciones que se aprecian corresponden a entrado el siglo XX. T. Elías, 2018. 


\title{
El hospital, casa y convento de Nuestra Señora Santa Ana de la ciudad de San Miguel de Piura y sus posesiones artísticas
}

\author{
Nuestra Señora de Santa Ana -hospital, house and convent in San Miguel de Piura city- \\ and its artistic possessions
}

\author{
Pável Elías Lequernaqué | Cristina Vargas Pacheco \\ Universidad de Piura, Perú \\ jorge.elias@udep.pe | cristina.vargas@udep.pe \\ https://orcid.org/0000-0002-4626-0057 | https://orcid.org/0000-0003-2997-264X
}

\begin{abstract}
Resumen
El establecimiento de la ciudad de San Miguel de Piura, primera fundada en el Pacífico sur (1532), supuso, como en otros casos, la fundación de equipamientos básicos para la vida de su población, entre los que figuró el Hospital de Santa Ana. Con los sucesivos traslados de la ciudad, la administración del nosocomio recayó en manos de la Orden Betlemítica, la que administró diferentes instituciones similares en la América virreinal. En Piura, esta institución gozó de gran fama, acogiendo enfermos de diferentes latitudes. Además de ello, contó con iglesia, convento y camposanto, los cuales, de acuerdo a un documento hallado en el Archivo Regional de Piura (ARP) y otras fuentes primarias, contaron con gran variedad de bienes artísticos religiosos, donde
\end{abstract}

\begin{abstract}
The establishment of San Miguel de Piura, first city founded in South Pacific (1532), involved setting-up all the basic equipments for living there, one of them the Santa Ana's Hospital. As the city was relocated few times, the hospital was put in charge of Bethlehem Order, which managed other similar institutions in colonial America. In Piura, this hospital reached a very good reputation, and sick people from another cities came there for attention. The Hospital also included a church, a convent and a cemetery, places that-according to the documentation reviewed-owned an important number of religious artistic goods, specially related to Virgin of Bethlehem's advocation, although their whereabouts is unknown today.
\end{abstract} posesiones artísticas", Atrio. Revista de Historia del Arte, n. ${ }^{\circ} 24,2018$, págs. 84-101.

Copyright (c) 2018 Pável Elías Lequernaqué y Cristina Vargas Pacheco. Este es un artículo de acceso abierto distribuido bajo los términos de la licencia Creative Commons Attribution-NonCommercial-ShareAlike 4.0. International License (CC BY-NC-SA 4.0) 
primó la advocación de la Virgen de Belén, de los cuales hoy se desconoce su paradero.

Palabras clave: Hospital; convento; Nuestra Señora de Santa Ana; Betlemitas; Piura; bienes artísticos.
Keywords: Hospital; convent; Nuestra Señora de Santa Ana; Bethlehemite; Piura; artistic properties.

"En la ciudad de San Miguel de Piura está un hospital fundado de la advocación de Señora Santa Ana... y es uno de los más esenciales del reino del Perú por ser la escala por donde suben los que vienen a él y continuamente está lleno de enfermos...". [Archivo Regional de Piura, Corregimiento, legajo 12, expediente 195]

Introducción

Uno de los hospitales de mayor importancia en el área norte del Virreinato peruano fue el de Nuestra Señora de Santa Ana, también denominado hospital de "Belén", debido a la cesión de su administración a la Orden Betlemita a partir de 1678. Era muy importante y estratégica su ubicación dado que, al ser el puerto de Paita "la puerta de entrada al Perü", por San Miguel pasaban la mayoría de viajeros que preferían realizar por tierra, el viaje a la ciudad de Los Reyes u otras partes del territorio virreinal ubicados al sur, dado que era más rápido y presentaba menos peligros que el viaje marítimo.

Muchos de estos viajeros, entre los que se encontraban comerciantes de la Audiencia de Quito y otras latitudes, arribaban con problemas de salud, graves o livianos, que necesitaban controlar en algún hospital, siendo el hospital de Piura, el primero de la Audiencia de Lima.

Con el paso del tiempo, este hospital va ganando buena fama. La cita inicial que hemos incluido, que data de 1648, da cuenta de esto. El cosmógrafo y doctor en medicina Cosme Bueno, señalaba a mediados del siglo XVIII que la ciudad de San Miguel de Piura contaba con un "Hospital de Religiosos Bethlemitas, bien asistido, en que entre otras enfermedades se cura el Gálico [o "bubas", hoy llamada sifilis] con menos dificultad que en otras partes por ser el temperamento favorable para esto, por lo que concurren de muchas provincias a curarse los que padecen de aquella dolencia"2. El jesuita Mario Cicala, por la misma época, coincide con lo señalado por Bueno, dándonos noticias referidas a la muy buena calidad de este establecimiento -tanto en lo concerniente a sus conocimientos médicos como a su infraestructura-, por lo que acudían personas de diferentes regiones, buscando el restablecimiento de su salud ${ }^{3}$.

El presente artículo se basa, entonces, en un expediente inédito, ubicado en el Archivo Regional de Piura, bajo el nombre de Razón del Inventario de los bienes, muebles, y raices de derecho que pertenece á este Nuestro convento Hospital de Señora Santa Ana dela ciudad de Piura, y entrega que haze el Reverendo Padre Fray Casiano dela Santísima Trinidad al Reverendo Padre Presidente Fray Fernando de Belén, y en su nombre a su Vice Prefecto fray Benito del Carmen [sic] $]^{4}$, fechado en el tardío Virreinato, en 1813. Dicho documento se convierte en una

1. GLAVE TESTINO, Luis Miguel, "La puerta del Perú: Paita y el extremo norte costeño, 1600-1615", Boletín del Instituto Francés de Estudios Andinos, 22 - 2, 1993.

2. COSME BUENO, Francisco Antonio, Colección geográfica e histórica de los arzobispados y obispados del Reyno del Perú, con las descripciones de las provincias de su jurisdicción, Lima, s.n., 1759-1776, pág. 55.

3. CICALA, Mario, S.J., Descripción Histórico-topográfica de la provincia de Quito de la Compañía de Jesús, Quito, Biblioteca ecuatoriana "Aurelio Espinosa Polit", 1944.

4. El expediente analizado se conserva en el Archivo Regional de Piura, Intendencia, legajo 72, expediente 1483, año 1813. 
suerte de grabado detallado del espacio arquitectónico de la iglesia, convento, hospital, escuela y camposanto; así como del mobiliario que estos poseían y de la vida cotidiana de la orden, en relación a la ciudad; casi un siglo antes de su desaparición definitiva tras el importante seísmo ocurrido en la ciudad, en el año 1912. Resulta, por tanto, una fuente excepcional para reconstruir parte del patrimonio eclesiástico virreinal hoy inexistente o cuyo paradero se desconoce; más aún cuando existen otras escasas fuentes -entre ellas, las fotográficas- que permitan conocer más a detalle su estructura con relación al espacio urbano donde se ubicós.

De igual modo, el expediente, así como otras fuentes archivísticas del siglo XVI en adelante, nos permiten explorar la manera en que fueron acumuladas dichas posesiones, gracias a la utilización de diferentes estrategias económicas como los censos y capellanías, lo cual nos permite acercarnos a un espacio sacro asociado a lo civil (hospital) y observarlo tal como lo vieron sus feligreses; así como a ciertas prácticas de religiosidad local de esta región del Virreinato peruano.

\section{Breve recorrido por la historia del hospital de San Miguel de Piura}

La historia del hospital de Santa Ana de la ciudad de San Miguel de Piura, se puede dividir en dos etapas. Una primera que va desde sus orígenes en la ciudad, aproximadamente en 1535 y hasta 1678, fecha que marca el inicio de la segunda etapa de su historia, cuando la orden de Belén asume la administración del hospital, así como de la capilla adyacente y se inicia su periodo de crecimiento, tanto de las instalaciones, de la fama de la institución hospitalaria, como de sus bienes. Pasaremos a desarrollar brevemente estas etapas.

\section{Los inicios}

La ciudad de San Miguel de la Nueva Castilla, primera ciudad hispana en el Pacífico Sur, fue fundada por el capitán Francisco Pizarro a mediados de agosto de 1532, en un primer asiento ubicado muy cerca de un poblado indígena Tallán, denominado Tangarará, en un área cercana a la desembocadura del río Chira. A pesar que Pizarro repartió entre los primeros vecinos de San Miguel solares y fijó terreno para iglesia, casa del cabildo, casa del teniente de gobernador, mesón, pulpería, hospital, entre otros lugares públicos y privados, lo cierto es que esta planificación nunca se llevó a cabo en dicho primer asiento.

Poco más de dos años después, a fines de 1534, los vecinos junto a Diego de Almagro, mudaron la ciudad, aún en sus albores, al territorio del cacique Piura, a orillas de otro río de la zona que luego recibió el nombre también de Piura. En este segundo asiento, los vecinos sí van a poder erigir una verdadera ciudad, que giraba en torno a una gran plaza mayor ${ }^{6}$. Allí, entre los primeros recintos públicos que se van a construir, en un lugar privilegiado y fundado a instancias del cabildo de la naciente ciudad, estuvo el hospital. En este caso particular, es entendible que ocupara uno de los sitios más importantes, debido a que entre los primeros vecinos de ella estuvieron muchos conquistadores enfermos y con malestares propios de la guerra. Posteriormente, con los sucesos de la guerra de los encomenderos, en la siguiente década, donde San Miguel

\footnotetext{
5. La información contenida en esta Relación, también nos permite conocer los títulos albergados en su biblioteca, los medicamentos empleados en el hospital, como otros aspectos del quehacer de la orden, los cuales, sin embargo, no serán abordados en este trabajo en la medida en que presentamos un primer acercamiento al ámbito arquitectónico-artístico de este complejo.

6. Hoy, el yacimiento denominado "Piura la Vieja" por estar situado en un poblado homónimo, viene siendo estudiado por la facultad de Humanidades de la Universidad de Piura, junto con la Municipalidad Distrital de la Matanza y la escuela de Arquitectura de la Universidad Politécnica de Madrid, dentro del proyecto denominado: "San Miguel de Piura: primera fundación española en el Perú, 1534-1578".
} 
de Piura y su jurisdicción tuvieron un protagonismo importante en la primera parte de este suceso bélico, se hará más necesario el contar con una enfermería u hospital donde se puedan atender heridos y enfermos.

La Corona fue consciente desde un primer momento de la importancia de tener un hospital en la primera ciudad fundada en territorio de los Andes, por ello, incluso antes del primer traslado de la ciudad, se preocupó por su construcción, poniendo a disposición del cabildo de San Miguel y sus vecinos una serie de medidas encaminadas a su concreción. Así tenemos que por Real Cédula del veintiuno de mayo de mil quinientos treinta y cuatro, Carlos I, ante solicitud de merced presentada por Hernando Pizarro, en nombre del cabildo, vecinos y pobladores de San Miguel señalaba que:

"somos informados que en la provincia del Perú, cuya gobernación tenemos encomendada al capitán Francisco Pizarro, hay necesidad de se hacer en ella un hospital para que los pobres que [en] ella hubiere sean curados y albergados [...] hacemos merced al hospital que se ha hecho o hiciere en la dicha provincia de la escobilla y relaves de todo el oro y plata y otros cualesquier metales que se fundiesen en las cajas de fundición de la dicha provincia, para que de lo que de ello se hubiere se gaste y distribuya en el edificio del dicho hospital y en lo necesario para los pobres y enfermos que en el dicho hospital se acogieren [... ." 7 .

Se puede apreciar una preocupación muy grande en la Corona española por la salud secular y espiritual de sus súbditos. En 1541, poco antes del dictamen de las Leyes Nuevas, Carlos V, proclama: "Encargamos y mandamos a nuestros virreyes, audiencias y gobernadores, que con especial cuidado provean, que en todos los pueblos de españoles e indios de sus provincias y jurisdicciones, se funden Hospitales donde sean curados los pobres enfermos y se exercite la caridad Christiana"; disposición que será reforzada por su sucesor, Felipe II, estableciendo que "cuando se fundare una población, se tenga cuidado de construir un hospital para pobres y enfermos de enfermedades que no sean contagiosas y junto a ellos, las iglesias".

Para 1548, ya el hospital de la ciudad está construido aunque no sabemos si en su totalidad. Ha podido salir adelante gracias a mercedes como la que hemos señalado en el párrafo anterior, pero también a donaciones, mandas y herencias otorgadas en los testamentos de vecinos piuranos. Una de las donaciones más antiguas que hemos podido encontrar se remite a principios de 1548, cuando en su testamento del veintitrés de enero de dicho año, Antón de Carrión vecino de Piura, deja establecido en su última voluntad que mandaba "al hospital desta ciudad para rrem(edi)o de los pobres quarenta pesos de oro con que se compre una vaca preñada o dos para que con las que tiene le dé rrenta para la sustentaci(ón) del d(ic)ho hospital e pobres del [... J". Otros vecinos, hacen lo mismo que Carrión otorgando en sus testamentos, como bienes para el hospital este tipo de ganado u otro, como por ejemplo el cabrío o el ovejuno. El legado de estos primeros vecinos debió ser muy importante para la consolidación y mantenimiento del hospital, ya que cien años después, en 1648 se habla de una manada de ganado cabrío y ovejuno que los vecinos de San Miguel "muchos años á le dieron de limosna" al hospital de Santa Ana de dicha ciudad ${ }^{10}$. Por eso es que desde aproximadamente 1628, el gobierno virreinal le otorgaba a este hospital un indio mitayo del pueblo de Catacaos ${ }^{11}$, para la guarda de dicho ganado.

7. Archivo General de Indias (en adelante AGI), Lima 565, L1, f. 182 v.

8. Recopilación de Leyes de Indias, L. I, leyes I y II, 1681. LASTRES, Juan, Historia de la Medicina Peruana, Vol. II, Lima, Universidad Nacional Mayor de San Marcos, 1951, pág. 39.

9. AGI, Contratación 5575, N15, año 1548.

10. Archivo Regional de Piura, Corregimientos, legajo 12, expediente 195, año de 1670.

11. Catacaos fue un pueblo reducción de indios, ubicado al suroeste de la ciudad española de San Miguel de Piura en su última ubicación (1588), y cuyos indios tributarios acudían a prestar fuerza laboral obligatoria (mita) a las haciendas y estancias de los vecinos españoles, al igual que los otros 
En esta primera etapa, el funcionamiento de este recinto estuvo dirigido por personas de diversa procedencia, incluidos religiosos, por lo que contaba seguramente con enfermeros ${ }^{12}$, algún médico cirujano, "farmacéuticos", pocas camas, medicinas y personal que atienda y, donde el mayordomo era algún miembro del cabildo de la ciudad o vecino connotado del mismo. Además, como señalábamos líneas arriba, al costado del hospital o enfermería ubicados en plena plaza mayor, se construiría muy pronto una pequeña capilla, que luego, a principios del siglo XVIII se convertiría en iglesia, todo ello bajo la advocación de Nuestra Seńora de Santa Ana.

A lo largo del siglo XVI y XVII, se incrementan y acumulan los bienes muebles del hospital de la ciudad, así como también los bienes inmuebles del mismo, sea por donación o legado, así como también por compra que se hace de dichos bienes. Un ejemplo de donación, lo tenemos en la que realiza en su testamento María González, de "dos sillar de sentar, las cuales mando se den de limosna al hospital de señora Santa Ana de esta ciudad, para que se sienten los pobres de ép'13.

Respecto a la segunda modalidad (compra de bienes), tenemos que el local del primigenio hospital va creciendo por la adquisición que se hace de los solares adyacentes que les pertenecían generalmente a vecinos encomenderos de la ciudad. Así es como en mayo de 1611, el hospital de San Miguel compró al encomendero Ruy López Calderón, "un pedazo de solar con lo en él labrado y edificado de adobes [...] que linda con el dicho hospital"14, al precio de 100 pesos de a ocho reales.

Para estas compras hacía falta pesos o tejos de oro o plata del cual se beneficiaba este hospital, entre otras formas, con cantidades de pesos que diferentes personas le aportaban mediante sus testamentos. En mayo de 1602, Miguel de Ayeste deja estipulado en su testamento que de sus bienes se le den al "hospital de la ciudad de San Miguel de Piura y a su mayordomo en su nombre cient pesos de a ocho reales" ${ }^{15}$.

\section{La orden de los Betlemitas y el Hospital de Santa Ana en la ciudad de Piura}

Una segunda etapa se inicia en 1678 con la llegada de la orden de Belén a la ciudad y el encargo que le da el cabildo para que se hagan cargo del hospital dada la rápida experiencia que en el rubro, habían ido adquiriendo en otros lugares de la América. En setiembre de 1712, los religiosos de esta orden solicitaron autorización al cabildo para erigir una verdadera iglesia, la que se mantuvo en pie hasta el terremoto de 1912. Adosada al hospital se encontraba la casa de los dichos hermanos betlemitas, la que albergaría, durante el siglo XVIII, un número de religiosos que oscilaba entre diez y quince. Pero, ¿de dónde procedía esta orden?, ¿quién la había fundado?, ¿a qué se dedicaban los miembros de la orden de Belén? A estas interrogantes pasaremos a dar respuesta a continuación.

pueblos de indios de la jurisdicción. Hoy en día es un distrito de la provincia de Piura, reconocido por su variada artesanía (alfarería, orfebrería, cestería) y su patrimonio inmaterial (festividades y gastronomía).

12. El único nombre que hemos podido ubicar de un enfermero del hospital en el siglo XVII es el del hermano Andrés, hijo legítimo de Juan Bravo y de Catalina Adame, quien en su testamento del 16 de agosto de 1611, declaraba haber sido enfermero mayor (esto nos habla de una jerarquía entre los enfermeros, por lo que también debió haber habido enfermero menor) del hospital de Santa Ana de Piura, durante muchos años. Ver: ARP, Notarial Colonia, legajo 22, protocolo 9, año de 1611. Notario: Pedro Marqués Botello.

13. Archivo Regional de Piura, Notarial colonia, legajo 38, protocolo 10, año de 1612. Notario: Pedro Marqués Botello. El testamento tiene fecha de 24 de enero de 1612

14. Archivo Regional de Piura, Notarial colonia, legajo 22, protocolo 9, año de 1611. Notario: Pedro Marqués Botello.

15. Archivo Regional de Piura, Notarial colonia, legajo 31, protocolo1, año de 1602. Notario: Francisco de Morales. 
La orden de los Betlemitas

La Orden de Belén o Betlemita fue fundada inicialmente como la Hermandad de Nuestra Seńora de Belén, por el tinerfeño Pedro de San José Betancourt en la Antigua, Guatemala, en 1658, ante las ingentes necesidades educativas y de salud de las poblaciones indígenas ${ }^{16}$. Tiempo después de la muerte del fundador y ya habiendo asumido el liderazgo Fray Rodrigo de la Cruz, en 1687 la hermandad recibe la categoría de Orden. Precisamente, sería este último personaje quien redactaría las "Constituciones" que los rigieron, las que fueron aprobadas por el Papa Inocencio XI y se ocuparon considerablemente de regular el funcionamiento de sus hospitales. Asimismo, estas favorecieron, en lo sucesivo, la expansión de la orden ${ }^{17}$. De ese modo, los Betlemitas fundarían hospitales en los territorios de los virreinatos de Nueva España y del Perú. En este último, los establecimientos se instalaron en Potosí, Cajamarca, Chachapoyas, Trujillo y, el que es materia de esta investigación, Piura.

Estas necesidades y tareas educativas y de salud, como explica Juan Lastres -citando a Paz Soldán-, fue la mayor de las veces, delegada a las órdenes hospitalarias, siendo la orden más reconocida en Hispanoamérica, la de los Betlemitas, seguida por aquellas bajo el patronato de San Camilo y San Hipólito. Esta preocupación por los súbditos, añade Lastres, recuerda esa visión complementaria en que la Corona, por una parte, entendía que ejercía un "derecho divino" sobre los territorios dominados, pero también un "deber divino" de velar porque la piedad cristiana aliviara la vida de sus súbditos ${ }^{18}$.

\section{Los Betlemitas y el hospital de Santa Ana de Piura}

Como ya hemos señalado, la presencia de la orden de Belén en nuestra ciudad data de 1678 y, corresponde al período en que los hermanos betlemitas asumen el encargo de administrar el hospital, asumiendo, desde entonces también el nombre de Hospital de Belén ${ }^{19}$, siendo el primer religioso de la orden en llegar a Piura, Fray Bartolomé de la Cruz, que venía procedente de la ciudad de Cajamarca y que hacia 1721, sería prefecto de la orden. Esta rápidamente recibió la misión de hacerse cargo de otros hospitales en el virreinato peruano, como el de Lima y Cajamarca ${ }^{20}$.

Un siguiente testimonio de este hospital procede del relato del jesuita Mario Cicala. En su visita a los territorios de la Compañía de Jesús, de la jurisdicción de la Provincia de Quito, en la segunda mitad del siglo XVII, describe el hospital como "famosísimo en toda la América Meridional; [siendo] la botica una de las mejores de todo el Perú"; a lo que atribuía la concurrencia de pacientes de todo el Virreinato, así como también de los territorios de Panamá, Guayaquil, Popayán, Chile y, quizás de toda la América Meridional, así como también al "clima sequísimo, cálido y saludable; [asi como] a las vituallas, carne de singularísima calidad y los medios de los que dispone, [que permiten] curar con gran comodidad y brevedad y facilidad, las enfermedades más crónicas y arraigadas en los pacientes" 21 .

\footnotetext{
16. FAJARDO ORTíZ, Guillermo, "Algo sobre los betlemitas y sus hospitales en Hispanoamérica", Revista de la Facultad de Medicina de la UNAM, Vol. 45, n. ${ }^{\circ}$ 6, noviembre-diciembre, 2002, pág. 261.

17. En el artículo citado, Fajardo comenta esta "Constitución" que regulaba las normas de funcionamiento (como la acogida de pacientes, no discriminación de casta o "nación", entre otros temas) del hospital primigenio. Ibídem, pág. 262.

18. LASTRES, Juan, Historia de la Medicina Peruana..., op. cit., págs. 39-40.

19. ROBLES RÁZURI, Carlos, Historia de Piura. Piura, Concejo Provincial de Piura, Inspección de Biblioteca y Museo, 1973, pág. 6.

20. ALVARADO CHUYES, Juan José, Temas: Piuranísimos (Lugares), Piura, Imnorpe, 1992, pág. 61.

21. CICALA, Mario S.J., Descripción Histórico-topográfica..., op. cit., pág. 537.
} 
De su descripción se puede saber que el complejo estaba constituido por hospital, iglesia y convento. Este último era de "dos plantas de sólida construcción, maciza, tal vez de cal y ladrillo. Forma un cuadrado perfecto, con graciosísimo patio dotado de corredores y pórticos sostenidos en el piso bajo y el alto por pilastras octogonales". ${ }^{22}$ El Hospital, por su parte, tenía la fachada de pie hacia la Plaza Mayor; y contaba con salas independientes y separadas por sexo, para sacerdotes y religiosos; otra para personas civiles y nobles; una tercera, para artesanos y "toda clase de personas"; una cuarta para mujeres. La quinta, se dedicaba a los pacientes de "morbo gálico" o "bubas"; y, la sexta, a los que tenían dolencias como el reumatismo, parálisis, lepra o epilepsia ${ }^{23}$. No obstante, el jesuita no se detiene en la descripción de las posesiones al interior de la iglesia, aunque sí remarca las ingentes rentas del Hospital, lo que también permitiría entender la cantidad de bienes contenidos y que se revelan en la Relación antes mencionada.

En 1783, el obispo Baltasar Jaime Martínez de Compañón realiza un viaje durante más de cinco meses, por su diócesis de Trujillo del Perú, en lo que constituyó la quinta visita episcopal realizada en el siglo XVIII en estos territorios ${ }^{24}$. En su camino, recoge testimonios gráficos de las gentes, costumbres, arquitectura, especies de flora y fauna, música, entre otros datos, dentro de una lectura influida por las ideas ilustradas del territorio administrado. En el plano que aparece en el libro primero, aparece la ciudad de Piura y signado con la letra "F" se indica sobre la Plaza Mayor, el "Hospital de Bethelemitas" [sic] (Fig. 1).

El hospital y su iglesia se mantuvieron en el mismo establecimiento principal hasta el devastador terremoto de 1912, el cual supuso un frustrado proceso de modernización urbana de Piura. Para entonces, el establecimiento había caído en un período de decadencia durante el siglo XIX, iniciado con la supresión de las órdenes hospitalarias en el contexto de las independencias ${ }^{25}$. En Piura, el período transicional culmina hacia 1837, cuando la administración de la institución pasa a manos de la Beneficencia pública ${ }^{26}$.

Ya en plena etapa republicana, este seguía siendo el único hospital de la ciudad. En un informe de 1868, el prefecto local especifica que "no solo se dá asila á la jente menesterosa de esta sección de la República sino á un número considerable de las otras i de extranjeros, atraidos por el beneficio del temperamento para las enfermedades sifiliticas" ${ }^{27}$. Para entonces, las únicas mejoras avizoradas radicaban en la erradicación del antiguo sistema de "cobachas" [sic], mediante la compra de catres de hierro ${ }^{28}$.

Tal sería el estado de abandono de la institución en los años subsiguientes que en 1892, su presidente, un patricio de la ciudad, Don Francisco J. Eguiguren, decide entregar la dirección del mismo a la Congregación de San José de Tarbes, establecida en Quito ${ }^{29}$. Sin embargo, el abandono del espacio secularmente ocupado, recién ocurrió tras el terremoto aludido, donde sus instalaciones, así como su iglesia, sufren importantes daños. En el informe oficial emitido por la Subprefectura a los pocos días de ocurrido el seísmo (Fig. 2), se

\footnotetext{
22. Ibídem.

23. Ibídem.

24. CHUNGA, Laurence, "La administración de los borbones", DEL BUSTO DUTHURBURU, José Antonio (dir)., ROSALES AGUIRRE, Jorge (coord.), Historia de Piura, Piura, Municipalidad Provincial de Piura - Universidad de Piura, 2004, pág. 301.

25. FAJARDO ORTíZ, Guillermo, "Algo sobre los betlemitas...", op. cit., pág. 263.

26. PAZ VELÁZQUEZ, Juan, Piura en el novecientos, Piura, Ediciones Juan Paz Velásquez, 2002, pág. 97

27. VARGAS MACHUCA, Francisco, Memoria razonada que Francisco Vargas Machuca deja a su sucesor en la prefectura del departamento de Piura, Lima, Imprenta Francisco García, 1863, pág. 30.

28. Ibídem.

29. ROBLES RÁZURI, Carlos, Historia de Piura..., op. cit., pág. 7.
} 
describe, entre los daños registrados que "la torre de la Iglesia de Belén, vino también al suelo, lo mismo que la pared de su sacristía [añadiéndose lineas después que habia] quedado en tan malas condiciones que ha habido necesidad de trasladas á los enfermos al edificio que se estaba construyendo al otro lado del rio" 30.

El establecimiento a cargo de los Betlemitas no solo sirvió como espacio de salud física, sino también espiritual, asilo y, en algún caso, prisión, a lo largo del tiempo. En un expediente sobre Esponsales incumplidos en el siglo XVIII, el joven que otorgó palabra de casamiento, solicita a la autoridad eclesiástica:

"y en nombre mio pídale que me saque de esta mi casa con la solemnidad necesaria y me ponga en depósito en el Hospital de Bethem [sic] que es mi voluntad Casarme con Vuestra merced y satisfacerle de este modo palabra y honor que le debo lo que juro cumplir por Dios y esta Señal de Cruz +" ${ }^{31}$.

El depósito en este lugar radicaba en la protección que los sitios eclesiásticos proveían, evitando la intromisión de la fuerza secular. En cuanto al segundo caso, este corresponde al siglo XIX y se trató de un inmigrante ilegal de nacionalidad china, que fue detenido y depositado en prisión en el Hospital de Belén, probablemente debido a su deplorable condición de salud ${ }^{32}$.

Una imagen de la iglesia y sus bienes artísticos en el siglo XVIII El expediente inicialmente enunciado nos da cuenta de la iglesia adyacente al convento, hacia 1813, pocas décadas antes de la transferencia de su administración a la Beneficencia Pública, probablemente en uno de sus momentos de mayor esplendor. Esta contaba con un altar mayor de tres cuerpos, así como cuatro retablos laterales "dos dorados y dos sin dorar"; presbiterio, sacristía -conectada con el claustro principal- y almacén. El espacio sacro y profano se encontraba diferenciado a través de una "mampara de madera de roble y sus zapatillas de algarrobo [árbol endémico de la zona], todo pintado de azul y blanco y que sirve de frente a la puerta principal"33.

En el altar mayor, la imaginería se plasmó tanto en lienzos como en bultos escultóricos. Entre las imágenes que se describen en el documento, se hallaba la de San Joaquín y Santa Ana, en peanas de madera dorada, de bulto entero, en madera policromada, la primera; y, la segunda, decorada con "sus diademas de plata con sus vestidos". De igual modo, una de la advocación de la Virgen de Belén, sentada sobre

"su trono dorado por dentro y fuera, sentada en su silla de madera dorada, su corona de plata y sus piedras falsas, con círculo de rayos de plata, un cetro de lo mismo, su media luna, estrellas y tres serafines [de plata], con su niño en los brazos, también coronado en plata" ${ }^{34}$.

Flanqueando estas esculturas, la de San José y San Juan de Dios, ambas de vestir. Finalmente, coronando el retablo, una lámina de la Santísima Trinidad, así como unas láminas de pequeño formato de San Agustín y Santa Rosa. Resulta interesante constatar que, al igual que la iglesia de Belén, en Cajamarca -

30. Archivo Regional de Piura, Sección Hemeroteca. El Registro Oficial, agosto de 1912.

31. Archivo Arzobispal de Piura y Tumbes: PER/AAPT/AH/COL/CAUS.CIV/LEG 5/60. Sobre este caso en particular, se puede consultar: VARGAS PACHECO, Cristina Milagros, Los esponsales en el derecho indiano en su aplicación en el partido de Piura, Piura, Tesis de pregrado en Derecho. Universidad de Piura, 2015, pág. 48.

32. Archivo Regional de Piura, Juzgado Primera Instancia. Causas Criminales y Administrativas. Legajo 288- Expediente 6217.Piura, 17 de abril de 1856.

33. Archivo Regional de Piura. Sección Intendencia, Legajo 72, expediente 1483, año 1813.

34. Ibídem. 


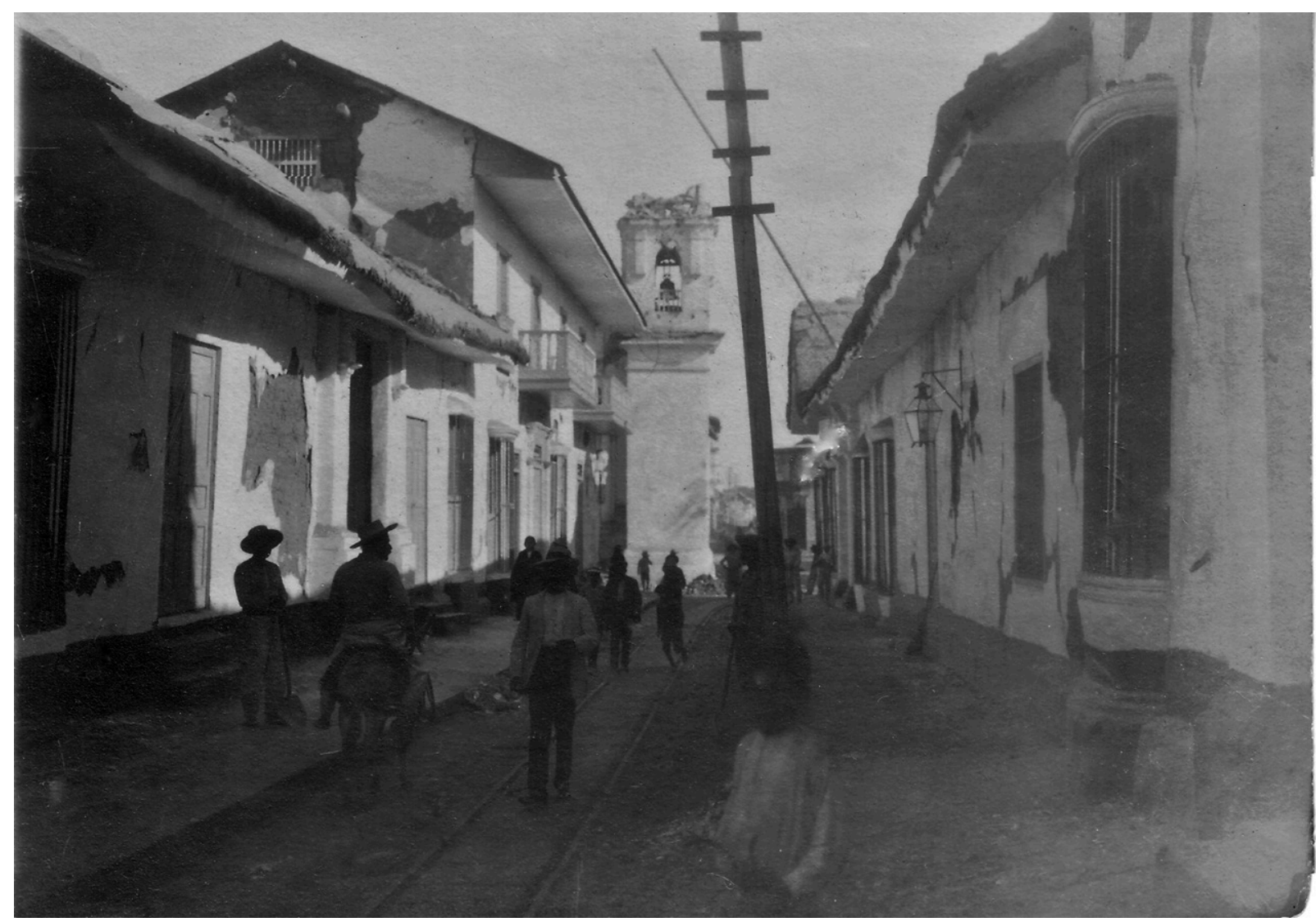

Fig. 2. Actual calle de La Libertad. Nótese al fondo una torre afectada, la cual corresponde a la iglesia del complejo de Belén -hoy desaparecida- (1912). Colección: Víctor Helguero Checa.

entregada a la custodia de la orden Betlemítica desde 1677 y que también administró el hospital para varones y el de mujeres, adjuntos-, la iconografía referente a la "Santa parentela" -como la denomina Moreno ${ }^{35}$, materializada en la representación de Santa Ana y San Joaquín-, se repite. Como ha descrito Zevallos y es tangible hasta el presente, en la gran portada de piedra, en estilo barroco andino, realizada a manera de retablo de tres cuerpos, se distinguen estas en el tercer cuerpo ${ }^{36}$. En esta magnífica portada, el grupo escultórico representando la Sagrada Familia, corona la misma.

La devoción a San José, tan presente en el complejo betlemita según la reiterada referencia a su representación en la imaginería, había cobrado importancia desde el siglo XVI, aunque de manera indirecta, asociado a la devoción a la Sagrada Familia, al Niño Jesús, así como a mártires y místicos de la Iglesia, dentro del programa didáctico emprendido por la Iglesia a partir del Concilio de Trento ${ }^{37}$. En el Perú, la fe josefina fue impulsada por el Arzobispo de Lima, Jerónimo de Loayza, también en el siglo XVI. Tal fue la devoción al

\footnotetext{
35. Sobre esta iconografía y sus variantes se puede consultar: MORENO CUADRO, Fernando, Iconografía de la Sagrada Familia, Córdoba, Caja Sur, 1994, págs. 44-50.

36. ZEVALLOS DE LA PUENTE, Andrés, Belén, Cajamarca, INC-Filial Cajamarca, 1980, págs. 9-10.

37. BARRIGA CALLE, Irma, Patrocinio, Monarquía y poder: el glorioso patriarca señor San Joseph en el Perú Virreinal, Lima, Pontificia Universidad Católica del Perú, Instituto Riva Agüero, Universidad Católica Sedes Sapientiae, 2010, pág. 31.
} 
santo que, desde fines de dicho siglo, se estipuló el 19 de marzo como fiesta de guardar. Ya para el siglo XVIII su devoción parece haberse consolidado en diferentes ámbitos del virreinato, como la capital y el Cusco ${ }^{38}$. Tal sería la devoción promovida a San José por la orden, que el Procurador General de la Religión Betlemítica, Fray Gregorio de la Concepción, solicita, en 1785, que "el Patriarca Sn Josef, sea Patrón Principal de la Religión”39.

En cuanto a la imagen central de la advocación mariana de "Nuestra Madre de Belén” -iconografía asociada con las Vírgenes de la ternura- ${ }^{40}$ resulta lógica su presencia en la iglesia administrada por la Orden. Querejazu ha advertido, para el caso americano y, particularmente del Alto Perú, que la devoción mariana se manifestó en la forma de devoción general, con advocaciones como la Inmaculada, la Candelaria, así como otras procedentes de las Sagradas escrituras, escritos teológicos o "las propagadas por órdenes religiosas" 41 , como parece ser en este caso. La otra manera fue la de las devociones particulares que adquieren relevancia, constituyendo muchas veces devociones regionales, como en el caso de la Virgen de Copacabana ${ }^{42}$. Precisamente, la advocación de la Virgen de Belén, muy venerada hasta el presente en el Cusco -considerada patrona de la ciudad-, ganó prestigio gracias al mito que envuelve el origen de la talla venerada. Esta devoción ha quedado plasmada en lienzos de la escuela cusqueña del siglo XVII y XVIII ${ }^{43}$, resaltando la obra de Basilio de Santa Cruz Pumacahua, "La Virgen de Belén con el Obispo Gaspar de Mollinedo como donante", actualmente parte de la colección de la Catedral del Cusco; así como la serie de pinturas de Santa Ana, representando las imponentes celebraciones del Corpus Christi, donde se desarrolla todo un programa iconográfico propio del Barroco y se evidencian aspectos relevantes de la sociedad cusqueña en la época del Obispo Mollinedo (siglo XVII). Tanto en el lienzo que representa el ingreso al templo de la procesión; como en aquella denominada "Carro de la Señora de Belén o de la Purificada", se hace tangible la devoción local a esta advocación ${ }^{44}$. La promoción de su culto se confirma cuando Pío VI concede "la facultad para celebrar en todos los sábados del año

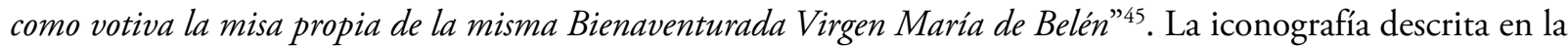
Relación, sin embargo, contiene reminiscencias de la iconografía de la Inmaculada concepción.

Los retablos menores alojados en los laterales de la iglesia, estuvieron consagrados a San José y la Virgen del Carmen, ambas imágenes de madera tallada y policromada, vestidas además con túnica, manto y ornamentos de plata, como corona y azucena. En el segundo altar, la imagen de la Virgen de los Dolores, ornamentada con túnica de terciopelo carmesí y manto de terciopelo azul y ornamentos de plata (cíngulo, estrellas y espaditas de plata); así como la de un Santo Cristo y una lámina de Nuestra Señora de Guadalupe, nos recuerdan el rápido tránsito de las devociones marianas americanas en los virreinatos ${ }^{46}$.

38. Ibídem, págs. 43-52

39. Archivo de Indias. Indiferente, 2923, N. 8. Agradecemos el dato a nuestra colega, profesora Ruth Rosas.

40. Sitio del Instituto Andaluz del Patrimonio Histórico. Entrada: Conservación y Restauración Virgen de Belén. Museo Catedralicio de Granada. Disponible en: http://www.iaph.es/web/canales/conservacion-y-restauracion/catalogo-de-obras-restauradas/contenido/virgen_alonso_cano.html (consultado en abril de 2017).

41. QUEREJAZU LEYTON, Pedro, "Iconografías marianas locales y la pintura de imágenes durante el siglo XVIII en la Audiencia de Charcas", Actas del Tercer congreso internacional del Barroco Americano: territorio, arte, escultura, Sevilla, Universidad Pablo de Olavide, 2001, pág. 360.

42. Ibídem.

43. Ibídem.

44. Archivo Digital del Arte Peruano (ARCHI). Museo de Arte de Lima. (Consultado en abril de 2017). También puede revisarse: BERNALES BALLESTEROS, Jorge, "El Corpus Christi: Fiesta Barroca en Cuzco", Primeras Jornadas de Andalucía y América, Vol 2, La Rábida, 1981, págs. 284-285.

45. Archivo de Indias. Indiferente, 2923, N. 8.

46. De acuerdo a una conversación personal con la historiadora Ruth Rosas, quien trabaja el tema de la religiosidad en la época virreinal en estos territorios, es probable que en este caso se trate de la advocación mariana surgida en México, la cual era principalmente representada en láminas, lienzos o medallas; a diferencia de la advocación de la Virgen de Guadalupe proveniente de Extremadura, cuya devoción en la zona de Pacasmayo 
El tercer y cuarto altares, colocados en los lados izquierdo y derecho de la nave, respectivamente, contenían imágenes de bulto de Santa Gertrudis y Santa Bárbara, la cual es representada con "un castillito de madera”, el cual no sería sino la torre, símbolo con el que se le asocia en ocasiones. El tercer altar se completa con dos urnas de madera dorada, una consagrada a San Lázaro y, la otra, al Nińo Dios recostado en su cama. Esta última imagen, según el recuento que nos brinda el documento, portaba "un rosario de perlas finas pequeñas con su cruz de oro, en una mano, un pajarito de oro con su perlita fina, [en la otra]" ${ }^{7}$. El último altar estuvo consagrado al Jesús Nazareno, representado de cuerpo entero y con su cruz al hombro.

La Iglesia también contó con un púlpito y coronación de madera tallada, ubicados sobre el lado derecho de la nave. En esta última, se podía observar una imagen de la Purísima Concepción y el Espíritu Santo tallados en madera. Un órgano "corriente con sus llaves", del que no se da mayores especificaciones y dos pilas bautismales, dos facistoles de madera ubicados en el Altar Mayor, hacheros, atriles de madera embutidos en marfil y carey, son algunos de los otros bienes descritos en el documento.

Además de los bultos escultóricos, la relación da cuenta de lienzos, aunque no se puede conocer a ciencia cierta su filiación estilística ni su paradero actual. Entre ellos figuraban cinco tablas del Evangelio de San Juan, un cuadro de Jesús Nazareno, siete cuadros de diferente dimensión de advocaciones marianas, entre las que se destaca la de Nuestra Señora del Carmen; un lienzo de San Agustín; y, uno de Nuestra Señora de los Dolores.

La profusión de imágenes -lienzos y esculturas- nos habla de una congregación con un ingente caudal, recibido de los censos, donación y otras rentas percibidas; pero también de un imaginario barroco con una gran profusión de imágenes que buscaban reforzar el mensaje católico en una población profundamente devota; incidiendo en tópicos vinculados a la concepción y vida familiar de Jesús (Jesús niño, la Sagrada Familia, la Virgen de Belén, San José), los padres de la Iglesia; así como mártires y santos asociados a los tópicos de la Sagrada Familia y la salvación de las almas (como en el caso de Santa Gertrudis y San Lázaro) y devociones americanas (Santa Rosa de Lima, canonizada en 1671; o la misma advocación novohispana de la Virgen de Guadalupe). Entrado el siglo XIX, es innegable el arraigo de la devoción y, por consiguiente, de la iconografía asociada a la Patrona de América y las Filipinas. Según Flores, "pretender [...] estudiar la iconografía completa de Santa Rosa de Lima es tarea poco menos que imposible, pues en las innumerables iglesias, conventos, monasterios, santuarios, beaterios y ermitas erigidos durante y después de la dominación hispánica en América, y hasta en oratorios particulares y modestísimas viviendas, no dejábase de rendir culto y veneración a la virgen limeña"48. Tal fue la devoción que, Flores concluye, siguiendo a los cronistas de la santa que, a su muerte "casi no habia hogar en el virreinato de Nueva Castilla, principalmente, donde no hubiese una imagen suya, fuese ésta pintada, esculpida o grabada" ${ }^{49}$, amén de la fe que se le profesaba en otros territorios bajo el dominio de la corona española.

(territorio comprendido en el área administrada por la Diócesis de Trujillo desde 1614), surgiría a fines del siglo XVI y se extendería en la zona norte. La primera escultura de esta advocación fue una réplica de la extremeña, donada por el capitán español Francisco Pérez de Lezcano, en gratitud por un milagro concedido. Una posterior fue mandada a confeccionar por los agustinos en 1626 . De estos bultos escultóricos, se hicieron réplicas que la historiadora ha podido identificar en diferentes testamentos de la época. La fuerza de la devoción a la Virgen de Guadalupe (Extremeña) es tan fuerte en Pacasmayo, hasta el presente, que ha sido declarada como parte del Patrimonio Cultural de la Nación, la Romería en su honor, según Resolución Viceministerial Diario Oficial "El Peruano". Resolución Viceministerial N 127-2014-VMPCIC-MC. "Declaran Patrimonio Cultural de la Nación a la Romería en Honor a nuestra Señora de Guadalupe". Lima 22 de noviembre de 2014, págs. 538116. Agradecemos los datos a Ruth Rosas Navarro.

47. ARP, Intendencia, Legajo 72, expediente 1483, año 1813.

48. FLORES ARAOZ, José, "Iconografía de Santa Rosa", MUJICA PINILLA, Ramón, et al., Santa Rosa de Lima y su tiempo, Colección Arte y Tesoros del Perú, Lima, Banco de Crédito del Perú, 1995, pág. 216.

49. Ibídem. 
En el documento se registra una gran cantidad de ornamentos, entendidos como vestiduras sagradas del oficiante, de diversos colores, de propiedad de la orden. Como apunta Victorio "los colores de los diversos ornamentos litúrgicos fueron elegidos en relación con el carácter del día, o de la función sagrada a celebrar" ${ }^{30}$. La simbología cristiana asociada a estos, permite entender su uso de acuerdo al calendario de la Iglesia. Los ornamentos blancos deben ser asociados al significado cromático. Este color estuvo asociado a la iluminación o a la teofanía", y es el color empleado en "los tiempos de Pascua de Resurrección, Navidad, Jueves Santo y en las fiestas de Nuestro Señor, la Virgen, los ángeles y los santos que no son mártires, misas de confirmación, bautismo y matrimonio; asimismo para la Epifanía, por el esplendor de la estrella que guía a los Magos, y la Purificación, debido a la pureza de María" 52 . Por su parte, el rojo, según Chevalier, como el blanco, "son colores consagrados a Jehovah como Dios de amor y de inteligencia" "53; pero como advierte el mismo autor, también asociados al poder desde la Antigüedad. Su uso en el teatro simbólico de la fe, está asociado a la sangre de Cristo y por ende, a su "Pasión, el Domingo de Ramos, Pentecostés (fuego y vida), Viernes Santo, la Santa Cruz [...], celebrar el nacimiento de los apóstoles, los Evangelistas y [los] mártires" ${ }^{\prime 4}$. En cuanto al verde ${ }^{55} \mathrm{y}$ al morado, su uso alude al Tiempo Ordinario y al tiempo de Adviento y Cuaresma, respectivamente ${ }^{56}$. Finalmente, el negro es asociado a la muerte y el duelo, "a la renuncia de la vanidad", por lo que, en el ámbito de la Iglesia, su uso se asocia a las misas de difuntos y al Viernes Santo ${ }^{57}$.

Entre los ornamentos de diversos colores inventariados en la Relación, se pueden destacar "un hornamento entero de brocato blanco que se compone de capa de coro, casulla y dalmáticas sin almaysal [sic] [quizás haciendo referencia a un "almaizar"] [...] con forros de tafetán rosado". El paramento de las prendas era de oro fino y la capa estaba unida con cuatro broches de plata. De igual modo, otra casulla de lama de plata con franja y cíngulo del mismo género; así como una capa de coro de raso con flores blancas y paramento de oro; "casulla, dalmáticas y almaisal [sic] [...] a flores fondo nácar con franja de oro y plata falsa ancha más paramentos corrientes", "dalmáticas, casulla, capa de coro de tafetán morado con franjas de plata todo corriente forrado en choleta [sic]; casullas de brocatillo morado a flores con franja calada de plata y forro de olandilla [sic]", "hornamentos negro de terciopelo que se compone de capa de coro, casulla, dalmáticas, manga de cruz, frontal, almaisal franjeado de plata falsa forrado todo en Olandilla amarilla y demás paramentos corrientes", entre muchos otros ornamentos.

Además de las prendas para el ritual, la orden también atesoraba una importante cantidad de bienes de plata labrada. Ya decía Cicala que entre los oficios que florecen en la ciudad de Piura, se encuentra el de "plateros" 58 , tradición que no ha hecho sino robustecerse con el tiempo, siendo que el trabajo artesanal de metalurgia en filigrana de esta región, ha sido designada como patrimonio cultural de la nación desde el año

\footnotetext{
50. VICTORIO CÁNOVAS, Emma Patricia, Los ornamentos litúrgicos: programa iconográfico y discurso. Las casullas peruanas del siglo XVIII en la catedral de Lima, Lima, Tesis para optar el grado académico de Magíster en Arte Peruano y Latinoamericano, Universidad Nacional Mayor de San Marcos, 2011, pág. 147

51. CHEVALIER, Jean y GHEERBRANT, Alain, Dictionnaire des symboles, París, Robert Laffont/ Jupiter, [1969], 1982, pág. 127.

52. VICTORIO CÁNOVAS, Emma Patricia, Los ornamentos litúrgicos..., op. cit., pág. 148, citando a RÉAU, Louis, Iconografía del arte cristiano, Barcelona, Ediciones del Serbal, [1957]-2000, pág. 93.

53. CHEVALIER, Jean y GHEERBRANT, Alain, Dictionnaire des symboles..., op. cit., pág. 833, citando a PORTAL, Frédéric, Des couleurs symboliques dans I'Antiquité et le Moyen Âge et les Temps Modernes, París, 1837.

54. VICTORIO CÁNOVAS, Emma Patricia, Los ornamentos litúrgicos..., op. cit., pág. 149

55. Sobre sus múltiples significados se puede consultar CHEVALIER, Jean y GHEERBRANT, Alain, Dictionnaire des symboles..., op. cit.

56. VICTORIO CÁNOVAS, Emma Patricia, Los ornamentos litúrgicos..., op. cit., págs. 152 y 156.

57. CHEVALIER, Jean y GHEERBRANT, Alain, Dictionnaire des symboles..., op. cit., págs. 671 y 674.

58. CICALA, Mario S.J., Descripción Histórico-topográfica..., op. cit., pág. 543.
} 
2010. Entre las posesiones de la orden, figuraban: incensarios con naveta y cuchara de plata, cálices (algunos de plata pura, otros sobredorados), platillos de vinagreras, salvillas de plata, campanillas, blandones, candelejas, candelejas, utensilios para producir hostias e incluso, "dos santos Cristos de plata con sus cruces pequeñas de madera".

Cabe destacar que, dentro de las descripciones vertidas en la Relación, algunos acápites se refieren a los ornamentos de las diferentes imágenes dispuestas en la iglesia. La de la Virgen de Belén, por ser la imagen principal, nos permite conocer la representación de esta advocación en estos territorios, a falta de lienzos conservados como en el caso de los mencionados para el Cusco. Las alhajas de la Virgen comprendían gargantillas de perlas falsas con doce cuentas de oro grandes, "otra de perlas de Chocón con una cruz grande oro y en ella veinte y tres esmeraldas y otra crucecita pequeña de oro"; zarcillos de metal con piedras falsas, otros de oro con perlas y otro con piedras de Bohemia; sortija de tumbaga, tembleques "el uno con una perla grande en medio y diez chicas alrededor y el otro en forma de Paloma con una perla grande y diez pequeños, todas finas"; así como potencias de oro y otras de plata.

Entre las prendas que pertenecían a la Virgen de Belén, figuraban

"un manto y túnica de glaze blanco forrado en tafetán rosado, el manto con franja de oro falso. De nuestra Señora, item un manto de brocado azul con franja de plata fina, forrado en tafetán nácar. Una túnica entera de espolín colorado con las traseras de perciana [sic] carmesi forrada de sandale azul con cinta al canto. Un manto de perciana amarilla a flores con franja ancha de plata fina forrado en angaripola azul a flores. Una túnica de griceta azul a flores menudas con galón [...] de oro, forrado en royal. Yten un manto de griceta nácar con galón de plata ancho forrado en sandales nácar. Yten media túnica de glaze fondo azul, forrada en sandalete nácar. Yten otra dicha de Espolín azul, y cuerpo blanco de brocato con mangas toda forrada en angaripola. Yten una túnica de velillo plateada sin forro. Yten un manto de brocato azul nuevo con chanveri falso forrado en sandalete amarillo y su túnica de lama [...] de oro nueva, un encage finos al cuello y las mangas con chanveri falso, forrado el cuerpo en sandalete amarillo. Yten un manto de brocato azul nuevo con chanverí falso forrado en tafetán verde y, por el centro o quarto del manto no tiene género y si forro. Yten dos túnicas de Lama de oro falso forradas, la una en tafetán nácar y la otra en royal, ambas del Niño Dios. Yten tres camisas viejas y dos fustanes de nuestra madre de Belén. Yten un velo de [...] forrado en sandalete rosado, franja de oro falso. Yten cinco tocas, todas viejas en varios colores. Yten un par de bultos de clarín con su encagito. Yten dos mariquillos de Espolin rosado forrados en sandalete azul [sic]"59.

\section{Otros espacios del complejo}

Resulta interesante el expediente pues permite conocer los diferentes espacios que comprendía el complejo, entre los que figuraban el claustro -alto y bajo-, una escuela, un archivo, una librería, una procuración, así como un camposanto y una capilla asociada a este.

Tanto en el claustro alto como en el coro, se destacan también bienes artísticos como "un quadro grande del nacimiento con su marco sobre dorado" o "un crucifijo con su [receña] pintada y puesto en firme", respectivamente. El coro comunicaba con la torre de la iglesia, donde se contenían cuatro campanas "una grande y las tres medianas". En la escuela, otras imágenes de Nuestra Señora de Belén, representada en un

59. Archivo Regional de Piura. Serie Intendencia. Legajo 72, expediente 1483, año 1813. 
pendón de raso; así como una imagen de Nuestra Señora y de San José, reafirman la presencia de estas devociones transmitidas por la Orden.

La capilla del Camposanto presentaba un altar realizado en adobe. En este se ubicaban un sagrario, sobre el cual existía un nicho conteniendo un crucifijo. El altar se encontraba coronado por un lienzo de la [Santa] Cena. Además, la capilla contaba con "catorce lienzos pequeños de ánimas sin mares, una cruz de madera [y], al frente un esqueleto sentado en su silla con su guadaña, toda de madera". El techo de la capilla fue confeccionado siguiendo la arquitectura local, con varas de algarrobo y esteras de carrizo. El campo santo se encontraba cercado con paredes de adobe y, a través de un callejón se comunicaba con el río principal que corre en la ciudad.

En cuanto a las enfermerías de varones y de mujeres, la primera, en forma de crucero, contaba también con un altar portátil y retablo y otros bultos escultóricos de madera tallada representando a la Virgen Dolorosa, San Juan, la Magdalena, un Niño [Jesús] y un San Felipe. Igualmente, lienzos de la Virgen del Carmen, de la Virgen de Guadalupe y de la Purísima, se ubicaban en la sala. En el caso de la segunda, también se describe un altar de adobe y sobre ese, un San José de bulto. En esta sala, la ornamentación resulta más modesta, indicándose la existencia de un único lienzo con el tema del nacimiento, ubicado en la testera.

Al parecer el caso de la Iglesia del Convento y Hospital de Belén sigue la tónica descrita por Gutiérrez de las capillas que, con el paso del tiempo, adquieren características propias de iglesias, "articulando la función hospitalaria con la vida parroquial”, lo que no significó la desaparición de las capillas interiores en las salas de enfermería, tal como ocurrió en el hospital de Belén o, incluso, en los claustros ${ }^{60}$.

\section{El origen económico de los bienes}

Conocido el programa iconográfico transmitido por la Orden Betlemita a través de su iglesia y complejo escolar y hospitalario, cabe preguntarse sobre el origen de la ingente cantidad de bienes artísticos poseídos.

Como ya señalábamos anteriormente, el hospital se beneficiaba de donaciones o legados que vecinos de la ciudad le otorgaban por testamento, sean estos bienes muebles, inmuebles o pesos. Esto, le permitía acumular efectivo para compra de terrenos, principalmente adyacentes al hospital primigenio, con la finalidad de ir acrecentando los servicios que daban. Así, luego del hospital surge, la capilla, a continuación la escuela, posteriormente el convento, la biblioteca, entre otros recintos que como hemos visto líneas arriba, se iban adornando de representaciones principalmente religiosas.

Otra forma de incrementar sus bienes, está dado por los censos, un sistema de rentas originado en Europa y luego trasladado a América y cuya práctica fue muy desarrollada en América. Caillavet define esta institución en términos generales "como un contrato firmado ante notario, según el cual una parte compra y la otra vende el derecho de percibir una pensión anual fija, en principio a perpetuidad”'61. Añade esta autora que a pesar de que los contratos de censos podían ser establecidos entre particulares, es significativo que en la gran mayoría de los casos, eran las entidades eclesiásticas (conventos, hospitales, capillas) las que se especializaron en la compra de

60. GUTIÉRREZ, Ramón, Arquitectura y urbanismo en Iberoamérica, Madrid, Ediciones Cátedra, 1983, pág. 265.

61. CAILLAVET, Chantal, Etnias del Norte. Etnohistoria e historia del Ecuador, Quito, Casa de Velázquez - IFEA - ABYA YALA, 2000, pág. 283. 
las rentas. Y se entiende esto debido a que muchas de las órdenes religiosas, así como religiosos del clero secular habían ido acumulando una gran cantidad de bienes, así como monetario que eran muy necesarios de insertar en la economía colonial, cuyo buen funcionamiento y equilibrio dependía en buena parte de dicha riqueza religiosa. Eran estas instituciones religiosas las que disponían de capitales suficientes para permitir el préstamo a otros, y quienes, inclusive habían fundado toda su economía sobre las inversiones que constituyeron los censos. Este es el caso del convento y hospital de San Ana, que fue acumulando bienes muebles e inmuebles, así como monetario que hizo que se convirtiera en la institución más importante de la ciudad que apelaba a los censos, para inyectar efectivo a los vecinos sanmiguelinos y poder realizar mejoras en sus casas, estancias o haciendas.

Uno de los censos más antiguos que hemos encontrado ${ }^{62}$ data de agosto de 1594 , cuando el vecino encomendero Gonzalo Prieto Dávila vendió y dio a censo al redimir y quitar al hospital de la ciudad, por intermedio de su mayordomo Juan de Morales, 48 pesos, 4 tomines y 6 granos y medio de plata de 9 reales el peso de censo y tributo anuales, pagados en dos pagas de 6 en 6 meses hasta redimirlos, por cuantía de 680 pesos de a 9 reales el peso, que Prieto había recibido de dicho hospital. El censo siempre contaba con un bien inmueble, sobre el que se imponía. En este caso específico, Prieto impuso el censo sobre su hacienda y estancia de "Nuestra Seńora del Rosario de Diapatera", con todo lo que en ella estaba labrado y edificado, incluido un molino de pan moler con todos sus aderezos y herramientas, así como dos esclavos negros llamados Miguel y Gregorio ${ }^{63}$. Este censo fue redimido en su totalidad tres años después, en agosto de 1597, cuando Gonzalo Prieto los 680 pesos de principal del censo, al entonces mayordomo del hospital Miguel de Salcedo, "en un tejo de oro de ley de 17 quilates y un grano que dijo valer la dicha cuantía".

Pero no todos los deudores de los censos tenían la posibilidad de redimir la cantidad principal prestada. Muchos iban pagando el monto anual estipulado, sin poder pagar el principal, esto en el caso de los censos redimibles, que para el caso de Piura, eran la mayoría ${ }^{64}$. Incluso había épocas malas para la agricultura y ganadería (presencia de lluvias exageradas como el hoy llamado fenómeno "El Niño" o, grandes períodos de sequía en la región) donde los deudores se veían imposibilitados de pagar las deudas, las cuales se iban acumulando año a año, hasta que llegaba el momento de la ejecución del bien inmueble sobre el que se había aplicado o gravado el censo. Es el caso de Gregorio Espinoza, quien en 1800, al no haber podido pagar durante muchos años la renta anual pactada con el hospital y convento de Santa Ana, en un concurso de acreedores que se le siguió, acaba perdiendo la hacienda Máncora, de su propiedad y que había impuesto a censo, en favor del "convento de Betlén" de Piura ${ }^{65}$. Esta es una de las principales propiedades inmuebles que tiene la orden en Piura hacia 1813, junto con la hacienda de Macará que tenía una casa con muebles y aparejos agrícolas, un potrero, ocho esclavos, dos mulas y veinte chacras cercadas en las orillas del río Chira, que los frailes de Belén tenían arrendadas a diferentes personas ${ }^{66}$.

Las estrategias puestas en marcha para incrementar su caudal, nos permiten comprender el fortalecimiento y expansión, en el tiempo, del complejo estudiado; así como la importante acumulación de bienes artísticos, de los que hemos presentado una selección. Todo ello, nos revela también, la importancia económica, social y política que la orden poseyó. Desde el punto de vista de las mentalidades, las obras de arte también nos permiten

62. Seguramente los hay más antiguos, pero la documentación más antigua sobre la ciudad que guarda el Archivo Regional de Piura, data de 1590. 63. Archivo Regional de Piura, Notarial Colonia, Legajo 21, protocolo 3, año 1594. Notario: Pedro de Castro.

64. Existían también los censos perpetuos, donde el pago era durante toda la vida del deudor, e incluso ésta pasaba a sus herederos.

65. Archivo Histórico de Límites del Ministerio de Relaciones Exteriores, PIRA-31, Caja 430, año de 1800.

66. ARP, Intendencia, legajo 72, expediente 1483, año de 1813. 
ir descifrando el influjo ideológico que la orden pudo tener, sobre el pueblo piurano, a lo largo de sus siglos de presencia, como divulgadoras de valores dentro de la tónica propia del Barroco; y nos aproximan, en el presente, a la religiosidad local vivida y al conocimiento del patrimonio religioso existente en aquel entonces en esta Diócesis.

Archivo Arzobispal de Piura y Tumbes:

Fuentes Primarias

PER/AAPT/AH/COL/CAUS.CIV/LEG 5/60.

Archivo Digital del Arte Peruano (ARCHI). Museo de Arte de Lima (consultado en febrero de 2017).

Archivo General de Indias

Lima 565, L1, f. 182 v.

Contratación 5575, N15, año 1548.

Indiferente, 2923, N. 8.

Archivo Histórico de Límites del Ministerio de Relaciones Exteriores:

PIRA-31, Caja 430, ańo de 1800.

Archivo Regional de Piura (ARP)

- Serie Corregimiento:

Legajo 12, expediente 195, año 1670.

- Serie Notarial Colonia:

Legajo 21, protocolo 3, año 1594. Notario: Pedro de Castro.

Legajo 31, protocolo1, año de 1602. Notario: Francisco de Morales.

Legajo 22, protocolo 9, año de 1611. Notario: Pedro Marqués Botello.

Legajo 38, protocolo 10, año de 1612. Notario: Pedro Marqués Botello.

- Serie Intendencia:

Legajo 72, expediente 1483, año 1813.

Juzgado Primera Instancia. Causas Criminales y Administrativas:

Legajo 288- Expediente 6217.Piura, 17 de abril de 1856.

- Serie Hemeroteca:

El Registro Oficial, N 29, Año XXXXII, Piura, 10 de agosto de 1912.

ALVARADO CHUYES, Juan José, Temas: Piuranisimos (Lugares), Piura, Imnorpe, 1992.

\section{Bibliografía}

BARRIGA CALLE, Irma, Patrocinio, Monarquía y poder: el glorioso patriarca señor San Joseph en el Perú Virreinal, Lima, Pontificia Universidad Católica del Perú, Instituto Riva Agüero, Universidad Católica Sedes Sapientiae, 2010.

BERNALES BALlESTEROS, Jorge, "El Corpus Christi: Fiesta Barroca en Cuzco", Primeras Jornadas de Andalucía y América, Vol 2, La Rábida, 1981, págs. 275-292.

COSME BUENO, Francisco Antonio, Colección geográfica e histórica de los arzobispados y obispados del Reyno del Perú, con las descripciones de las provincias de su jurisdicción, Lima, s.n., 1759-1776.

CAILLAVET, Chantal, Etnias del Norte. Etnohistoria e historia del Ecuador, Quito, Casa de Velázquez - IFEA - ABYA YALA, 2000. 
CHEVALIER, Jean y GHEERBRANT, Alain, Dictionnaire des symboles, París, Robert Laffont/ Jupiter, [1969], 1982.

CHUNGA, Laurence, "La administración de los borbones", DEL BUSTO DUTHURBURU, José Antonio (dir)., ROSALES AGUIRRE, Jorge (coord.), Historia de Piura, Piura, Municipalidad Provincial de Piura - Universidad de Piura, 2004, págs. 271-318.

CICALA, Mario, S.J., Descripción Histórico-topográfica de la provincia de Quito de la Compañia de Jesús, Quito, Biblioteca ecuatoriana "Aurelio Espinosa Polit", 1944.

DE PAREDES, Iulian, Recopilación de Leyes de los Reynos de la Indias, Madrid, 1681. Versión digital de la Biblioteca de la Universidad de Sevilla, Fondo Antiguo.

Diario Oficial "El Peruano". Resolución Viceministerial N 127-2014-VMPCIC-MC. "Declaran Patrimonio Cultural de la Nación a la Romería en Honor a nuestra Señora de Guadalupe”. Lima 22 de noviembre de 2014. FAJARDO ORTÍZ, Guillermo, "Algo sobre los betlemitas y sus hospitales en Hispanoamérica”, Revista de la Facultad de Medicina de la UNAM, Vol. 45, n. ${ }^{\circ}$ 6, noviembre-diciembre, 2002, págs. 261-263.

FLORES ARAOZ, José, “Iconografía de Santa Rosa”, MUJICA PINILLA, Ramón, et al., Santa Rosa de Lima y su tiempo, Colección Arte y Tesoros del Perú, Lima, Banco de Crédito del Perú, 1995, págs. 213-228.

GLAVE TESTINO, Luis Miguel, "La puerta del Perú: Paita y el extremo norte costeño, 1600-1615”, Boletín del Instituto Francés de Estudios Andinos, 22 - 2, 1993, págs. 497-519.

GUTIÉRREZ, Ramón, Arquitectura y urbanismo en Iberoamérica, Madrid, Ediciones Cátedra, 1983.

LASTRES, Juan, Historia de la Medicina Peruana, Vol. II, Lima, Universidad Nacional Mayor de San Marcos, 1951.

MARTÍNEZ COMPAÑÓN, Baltazar Jaime, Trujillo del Perú, Vol. I, Biblioteca Virtual Miguel de Cervantes (2015), disponible en: http://www.cervantesvirtual.com/obra-visor/trujillo-del-peru--volumen-i/html/, (consultada en febrero de 2017).

MORENO CUADRO, Fernando, Iconografía de la Sagrada Familia, Córdoba, Caja Sur, 1994.

PAZ VELÁZQUEZ, Juan, Piura en el novecientos, Piura, Ediciones Juan Paz Velásquez, 2002.

QUEREJAZU LEYTON, Pedro, "Iconografías marianas locales y la pintura de imágenes durante el siglo XVIII en la Audiencia de Charcas", Actas del Tercer congreso internacional del Barroco Americano: territorio, arte, escultura, Sevilla, Universidad Pablo de Olavide, 2001, págs. 359-370.

ROBLES RÁZURI, Carlos, Historia de Piura, Piura, Concejo Provincial de Piura, Inspección de Biblioteca y Museo, 1973.

Sitio del Instituto Andaluz del Patrimonio Histórico, Entrada: Conservación y Restauración Virgen de Belén. Museo Catedralicio de Granada, Disponible en: http:/www.iaph.es/web/canales/conservacion-y-restauracion/ catalogo-de-obras-restauradas/contenido/virgen_alonso_cano.html, (consultado en febrero de 2017).

VARGAS MACHUCA, Francisco, Memoria razonada que Francisco Vargas Machuca deja a su sucesor en la prefectura del departamento de Piura, Lima, Imprenta Francisco García, 1863.

VARGAS PACHECO, Cristina Milagros, Los esponsales en el derecho indiano en su aplicación en el partido de Piura, Piura, Tesis de pregrado en Derecho. Universidad de Piura, 2015.

VICTORIO CÁNOVAS, Emma Patricia, Los ornamentos litúrgicos: programa iconográfico y discurso. Las casullas peruanas del siglo XVIII en la catedral de Lima, Lima, Tesis para optar el grado académico de Magíster en Arte Peruano y Latinoamericano, Universidad Nacional Mayor de San Marcos, 2011.

ZEVALLOS DE LA PUENTE, Andrés, Belén, Cajamarca, INC-Filial Cajamarca, 1980.

Fecha de recepción: 15/05/2017 Fecha de aceptación: 27/07/2017 